\title{
Meningkatkan Hasil Belajar Matematika Melalui Media Bangun Ruang pada Siswa Kelas V Di SDN. No. 025/XI Desa Gedang
}

\author{
Neneng Triyuna ${ }^{1}$ \\ Guru di SDN. No. 025/XI Desa Gedang ${ }^{1}$ \\ Kecamatan Sungai Penuh, Kota Sungai Penuh, Provinsi Jambi
}

\begin{abstract}
This study aims to improve student learning outcomes in mathematics subjects by using space wake media in fifth grade students at SDN. No. 025/XI Gedang Village. This research is a classroom action research conducted in two cycles. Each cycle consists of four activities, namely planning, implementation, observation, and reflection. The study involved 20 fifth grade students year 2017/2018 at SDN. No. 025/XI Gedang Village, Sungai Penuh District, Sungai Penuh City, Jambi Province. This research was conducted for three months from September to November of 2017. Data collected in this study is students learning outcomes. Data were collected by observation and test. Furthermore, the data were analyzed by using descriptive analysis and simple statistical test. The results showed that student activity in learning improved. The increasing of student activity can be seen from from the increasing spirit of students in following the series of learning activities. Students are more active during lesson activities, students are able to ask questions, and students are able to answer the test questions well. Increasing of student learning activities are also in tandem with improving student learning outcomes. The average score of student learning outcomes increased from 61.50 before the action was given to 76.0 in cycle I and increased again to 80.25 in cycle II. Likewise with learning mastery. Learning completeness increased from $25.00 \%$ before the action was given to $80.00 \%$ in cycle I and increased again to $100.00 \%$ in cycle II. Thus, the use of build space media in the mathematics subjects can improve activity and learning outcomes of fifth grade students at SDN. No. 025/XI Gedang Village year 2017/2018.
\end{abstract}

Keywords: classroom action research, elementary school, learning outcomes, mathematics subjects, space building media

\section{PENDAHULUAN}

Pendidikan adalah usaha sadar dan terencana untuk mewujudkan suasana belajar dan proses pembelajaran agar peserta didik secara aktif mengembangkan potensi dirinya untuk memiliki kekuatan spiritual keagamaan, pengendalian diri, kepribadian, kecerdasan, akhlak mulia, serta keterampilan yang diperlukan dalam masyarakat, bangsa, dan negara.

Berbagai usaha pembaharuan kurikulum, perbaikan sistem pengajaran, peningkatan kualitas kemampuan guru, dan lain sebagainya merupakan suatu upaya ke arah peningkatan mutu pembelajaran. Banyak hal yang dapat ditempuh untuk mencapai tujuan tersebut, salah satunya adalah bagaimana cara menciptakan suasana belajar yang baik, mengetahui kebiasaan dan kesenangan belajar siswa agar siswa bergairah dan berkembang sepenuhnya selama proses belajar berlangsung. Untuk itu seharusnya guru mencari informasi tentang kondisi mana yang dapat meningkatkan pembelajaran di sekolah dasar.

Belajar dapat diartikan sebagai perubahan yang relatif menetap dalam tingkah laku yang terjadi sebagai suatu hasil dari latihan atau pengalaman (Purwanto, 1997). Salah satu masalah yang dihadapi oleh guru di Sekolah Dasar adalah hasil belajar siswa yang rendah. Hasil belajar didefinisikan sebagai kemampuan yang diperoleh siswa setelah melalui kegiatan belajar (Abdurrahman, 
2003; Dimyati dan Mujiono, 2006). Hasil belajar juga dijadikan sebagai salah satu indikator keberhasilan pembelajaran. Dengan demikian, masalah yang terjadi dalam pembelajaran perlu dipecahkan. Guru bertanggung jawab untuk memecahkan masalah tersebut.

Guru di SDN. No. 025/XI Desa Gedang menemukan masalah dalam pelaksanaan kegiatan pembelajaran di kelas, khususnya pada mata pelajaran matematika. Permasalahan yang terjadi adalah rendahnya hasil belajar matematika siswa. Hal ini terbukti bila diadakan ulangan harian per pokok bahasan selalu hasil belajar matematika di bawah rata-rata mata pelajaran lainnya. Hasil belajar matematika siswa lebih rendah lagi pada pokok bahasan jaring-jaring bangun ruang, luas permukaan bangun ruang, dan volume bangun ruang. Hasil tes penjajakan menunjukkan bahwa nilai yang diperoleh siswa berada pada rentang 50-75 dengan nilai rata-rata sebesar 61,5 . Hasil tes juga menunjukkan bahwa jumlah siswa yang tuntas (nilai memenuhi Kriteria Ketuntasan Minimal) sebanyak 25\% siswa. Hasil pengamatan menunjukkan bahwa ada beberapa hal yang menyebabkan hasil belajar siswa rendah, yaitu materi jaringjaring permukaan bangun ruang bersifat abstrak. Siswa sukar membedakan antara sisi pada bangun datar dengan sisi pada bangun ruang. Penyebab lainnya, siswa tidak menguasai konsep tentang jaringjaring bangun datar. Selain itu, penggunaan media yang kurang tepat atau tidak menggunakan media sama sekali yang dapat meningkatkan hasil belajar siswa.

Berdasarkan permasalahan tersebut, guru perlu menemukan solusi untuk memecahkan masalah tersebut. Caranya adalah penggunaan media pembelajaran. Media pembelajaran adalah berbagai jenis komponen dalam lingkungan siswa yang dapat merangsangnya untuk belajar (Sadiman, 1999). Menurut Halim (2002), media sebagai benda yang dapat dimanipulasi, dilihat, didengar, dibaca atau dibicarakan dan dipergunakan dalam kegiatan belajar mengajar.

Penggunaan media berperan penting dalam kegiatan pembelajaran, khususnya pembelajaran matematika. Menurut Ruseffendi (1993), media merupakan alat bantu untuk mempermudah siswa memahami konsep matematika. Alat bantu itu dapat berwujud benda kongkrit, seperti: batu-batuan, dan kacang-kacangan. Untuk menerapkan konsep bilangan, kubus (bendanya) untuk memperjelas konsep titik, ruas garis, daerah bujur sangkar dan wujud dari kubus itu sendiri, serta bendabenda bidang beraturan untuk menerangkan konsep bangun datar dan bangun ruang. Ruseffendi (1993) juga mengatakan bahwa keberhasilan pembelajaran $60 \%$ lawan $10 \%$ bila menggunakan media dibandingkan dengan tidak menggunakan media.

Untuk mengatasi masalah, media yang digunakan adalah media bangun ruang. Penggunaan media dapat dimanipulasikan, media merupakan lingkungan belajar yang sangat menunjang untuk tercapainya optimalisasi dalam pembelajaran, karena media merupakan jembatan belajar yang awalnya terdapat benda-benda konkret seperti pengalaman anak. Melalui media bangun ruang materi yang bersifat abstrak dapat menjadi konkret. Siswa akan mengetahui dan melihat komponen komponen bangun ruang. Dengan perantara media, siswa diharapkan dapat membedakan antara sisi pada bangun datar dan sisi pada bangun ruang. Selain itu dengan media siswa dapat melihat secara langsung bentukbentuk sisi dan sekaligus mengingat kembali tentang luas-luas bangun datar.

Penggunaan media dalam kegiatan pembelajaran membuat anak terlibat langsung dalam kegiatan pembelajaran. Menurut Rahmanelli (2005), apabila anak terlibat dan mengalami sendiri serta ikut serta dalam proses pembelajaran maka hasil belajar siswa akan lebih baik, 
disamping itu pelajaran akan lebih lama diserap dalam ingatan siswa.

Berdasarkan pemaparan tersebut, peneliti tertarik untuk melakukan penelitian tindakan kelas dengan judul "Meningkatkan Hasil Belajar Matematika melalui Media Bangun Ruang pada Siswa kelas V di SDN. No. 025/XI Desa Gedang”. Penelitian ini bertujuan untuk meningkatkan hasil belajar matematika melalui media bangun ruang pada siswa kelas V di SDN. No. 025/XI Desa Gedang.

\section{METODE}

Penelitian ini dilakukan di Kelas V SDN. No. 025/XI Desa Gedang, Kecamatan Sungai Penuh, Kota Sungai Penuh, Provinsi Jambi. Kegiatan penelitian berlangsung selama tiga bulan, yaitu sejak bulan September sampai dengan bulan November tahun 2017.

Subjek dalam penelitian ini adalah siswa kelas V SDN. No. 025/XI Desa Gedang yang berjumlah 20 orang. Subjek penelitian terdiri atas 8 orang siswa lakilaki dan 12 orang perempuan.

Jenis penelitian yang digunakan adalah penelitian tindakan kelas (classroom action research). Dengan penelitian tindakan kelas peneliti memberikan tindakan kepada subjek yang diteliti yaitu siswa kelas V. tindakan yang diberikan adalah penggunaan media bangun ruang.

Proses penelitian tindakan merupakan kerja berulang atau (siklus), sehingga diperoleh pembelajaran dapat membantu siswa dalam menyelesaikan soal tentang jaring-jaring bangun ruang dan luas pemukaan bangun ruang di kelas $\mathrm{V}$. Penelitian ini dilaksanakan dengan dua siklus. Satu siklus terdiri atas dua kali pertemuan. Setiap siklus dilakukan dengan empat kegiatan yaitu perencanaan, pelaksanaan, observasi, dan refleksi.

Data penelitian berupa hasil belajar yang dikumpulkan dengan observasi dan tes. Data selanjutnya diolah dengan analisis deskriptif dan uji statistik sederhana. Untuk mengetahui keberhasilan dalam pelaksanaan tindakan dari penggunaan media bangun ruang ini maka guru melakukan pengumpulan data dengan menggunakan tes. Hasil belajar yang diperoleh siswa dibandingkan dengan Kriteria Ketuntasan Minimal (KKM) 65,00. Siswa dikatakan tuntas jika nilainya lebih dari atau sama dengan 65,00.

\section{HASIL DAN PEMBAHASAN Kondisi Awal}

Pada awalnya peneliti menganalisis hasil belajar siswa di tahun ajaran yang sebelumnya. Hasil analisis menunjukkan bahwa hasil belajar siswa terendah terletak pada mata pelajaran matematika jika dibandingkan dengan mata pelajaran lainnya. Selanjutnya, peneliti melakukan pre-test untuk mengetahui kondisi awal. Hasil pre-test matematika kompetensi dasar 8.2 Menentukan jaring-jaring balok dan kubus siswa Kelas V SDN. No. 025/XI Desa Gedang tahun 2017/2018 disajikan pada Tabel 1.

Tabel 1 Hasil Pretest

\begin{tabular}{clccc}
\hline No & \multicolumn{1}{c}{ Nama } & Standar & Nilai & Keterangan \\
\hline 1 & Aldi Ardianysah & 65,00 & 70,00 & Tuntas \\
2 & Aurelina Asifa & 65,00 & 50,00 & Belum Tuntas \\
3 & Azizia Putri & 65,00 & 50,00 & Belum Tuntas \\
4 & Cantika Citrani & 65,00 & 60,00 & Belum Tuntas \\
5 & Farel Firdiansyah & 65,00 & 60,00 & Belum Tuntas \\
6 & Farid M. Afif & 65,00 & 60,00 & Belum Tuntas \\
7 & Fikri Hidayat & 65,00 & 60,00 & Belum Tuntas \\
8 & Fadila Rama Dandi & 65,00 & 60,00 & Belum Tuntas \\
9 & Hanifah Aulia & 65,00 & 60,00 & Belum Tuntas
\end{tabular}




\begin{tabular}{|c|c|c|c|c|}
\hline 10 & Luthfia Firas & 65,00 & 60,00 & Belum Tuntas \\
\hline 11 & M. Daffa Alifathul & 65,00 & 75,00 & Tuntas \\
\hline 12 & Miftahul Azwa & 65,00 & 60,00 & Belum Tuntas \\
\hline 13 & Neysa Aina & 65,00 & 60,00 & Belum Tuntas \\
\hline 14 & Nayla Putri Salsabila & 65,00 & 70,00 & Tuntas \\
\hline 15 & Nazwa Adriani & 65,00 & 60,00 & Belum Tuntas \\
\hline 16 & Rivana Astssahara & 65,00 & 60,00 & Belum Tuntas \\
\hline 17 & Reva Lina & 65,00 & 60,00 & Belum Tuntas \\
\hline 18 & Rani Safitri & 65,00 & 60,00 & Belum Tuntas \\
\hline 19 & Ridho Hamdani & 65,00 & 70,00 & Tuntas \\
\hline 20 & Rahul Adly & 65,00 & 65,00 & Tuntas \\
\hline \multicolumn{3}{|c|}{ Nilai terendah } & 50,00 & \\
\hline \multicolumn{3}{|c|}{ Nilai tertinggi } & 75,00 & \\
\hline \multicolumn{3}{|c|}{ Rata-rata nilai } & 61,50 & \\
\hline \multicolumn{3}{|c|}{ Siswa belajar tuntas } & $25,00 \%$ & \\
\hline \multicolumn{3}{|c|}{$\begin{array}{l}\text { Siswa belajar yang belum } \\
\text { tuntas }\end{array}$} & $75,00 \%$ & \\
\hline
\end{tabular}

Hasil penelitian yang disajikan pada Tabel 1 menunjukkan bahwa nilai terendah yang diperoleh siswa adalah 50,00 dan nilai tertinggi adalah 75,00 dengan nilai rata-rata sebesar 61,50 . Jumlah siswa yang telah belajar dengan tuntas adalah 25,00\%. Dengan demikian, masih banyak siswa yang belum mampu memenuhi nilai KKM sebesar 65,00. Hasil ini mendorong guru untuk memberikan tindakan sebagai upaya memecahkan masalah tersebut.

\section{Siklus 1}

Siklus I terdiri atas empat kegiatan, yaitu perencanaan, pelaksanaan, observasi, dan refleksi. Kegiatan perencanaan terdiri atas: merumuskan tujuan pembelajaran, memilih dan mengorganisasi materi ajar, memilih sumber belajar/media pembelajaran, menyusun skenario/kegiatan pembelajaran, dan menyiapkan alat evaluasi hasil belajar.

Pelaksanaan pembelajaran untuk Siklus I difokuskan untuk mencapai standar kompetensi yaitu 8. Memahami sifat bangun ruang sederhana dan hubungan antar bangun datar dengan kompetensi dasar adalah 8.1 Menentukan sifat-sifat bangun ruang sederhana. Setelah mengikuti kegiatan pembelajaran, siswa diharapkan dapat mengetahui sifat-sifat bangun ruang sederhana (balok dan kubus). Pelaksanaan kegiatan Siklus I terdiri atas tiga kegiatan yaitu kegiatan awal, kegiatan inti, dan kegiatan akhir. Kegiatan awal berupa guru mengucapkan salam; menyiapkan siswa, berdoa dan mengabsen kehadiran siswa; memberikan motivasi dan apersepsi; dan menyampaikan tujuan pembelajaran. Kegiatan inti, terdiri atas siswa mengamati aneka bangun ruang (kubus dan balok); siswa memberi nama bangun ruang tersebut; dengan bangun ruang, siswa menujuk sisi, rusuk dan titik sudut; siswa menghitung sisi, rusuk, dan titik sudut dari masing-masing bangun ruang; siswa mengukur panjang, lebar dan tinggi dari bangun datar; dan siswa menyebut bangun datar yang ada pada bangun ruang tersebut. Kegiatan penutup terdiri atas siswa dengan dibimbing oleh guru membuat kesimpulan mengenai materi pelajaran. Selain itu, guru memberikan tugas dan siswa mengerjakan tugas tersebut.

Guru melakukan pengamatan selama kegiatan pembelajaran dilakukan. Setelah melaksanakan tindakan pada siklus I diperoleh peningkatan hasil belajar matematika pada materi bangun ruang 
dengan menggunakan media bangun ruang. Pada siklus I disampaikan kompetensi dasar menentukan sifat-sifat bangun ruang sederhana dan menentukan jaring-jaring balok dan kubus. Analisis hasil penelitian berdasakan tindakan, observasi dari sikap dan perilaku siswa pada siklus I dapat dikemukakan sebagai berkut:

1. Siswa senang dengan mata pelajaran yang diajarkan.

2. Siswa tertarik dengan materi pelajaran.

3. Siswa cukup aktif mendengarkan penjelasan guru saat kegiatan pembelajaran berlangsung.

4. Siswa tertarik dengan media yang digunakan.

5. Sebagian siswa belum dapat menerima pelajaran yang diajarkan dengan baik.
6. Siswa cukup aktif menjawab pertanyaan guru, meskipun masih malu.

7. Semangat siswa dalam kegiatan pembelajaran berlangsung lumayan baik.

8. Keaktifan siswa dalam mengerjakan tugas masih perlu ditingkatkan.

9. Siswa belum dapat memecahkan masalah yang berkaitan dengan tugas dari guru dengan baik.

10. Siswa belum dapat mengerjakan soal tes dengan baik.

Selain peningkatan pada aktivitas belajar selama kegiatan pembelajaran berlangsung, peningkatan juga terjadi pada hasil belajar siswa. Hasil belajar siswa siklus I disajikan pada Tabel 2.

Tabel 2 Hasil belajar siswa Siklus I

\begin{tabular}{clccl}
\hline No & \multicolumn{1}{c}{ Nama } & Standar & Nilai & \multicolumn{1}{c}{ Keterangan } \\
\hline 1 & Aldi Ardianysah & 65,00 & 75,00 & Tuntas \\
2 & Aurelina Asifa & 65,00 & 80,00 & Tuntas \\
3 & Azizia Putri & 65,00 & 80,00 & Tuntas \\
4 & Cantika Citrani & 65,00 & 80,00 & Tuntas \\
5 & Farel Firdiansyah & 65,00 & 80,00 & Tuntas \\
6 & Farid M. Afif & 65,00 & 80,00 & Tuntas \\
7 & Fikri Hidayat & 65,00 & 75,00 & Tuntas \\
8 & Fadila Rama Dandi & 65,00 & 80,00 & Tuntas \\
9 & Hanifah Aulia & 65,00 & 60,00 & Belum Tuntas \\
10 & Luthfia Firas & 65,00 & 60,00 & Belum Tuntas \\
11 & M. Daffa Alifathul & 65,00 & 90,00 & Tuntas \\
12 & Miftahul Azwa & 65,00 & 60,00 & Belum Tuntas \\
13 & Neysa Aina & 65,00 & 80,00 & Tuntas \\
14 & Nayla Putri Salsabila & 65,00 & 80,00 & Tuntas \\
15 & Nazwa Adriani & 65,00 & 60,00 & Belum Tuntas \\
16 & Rivana Astssahara & 65,00 & 80,00 & Tuntas \\
17 & Reva Lina & 65,00 & 80,00 & Tuntas \\
18 & Rani Safitri & 65,00 & 80,00 & Tuntas \\
19 & Ridho Hamdani & 65,00 & 80,00 & Tuntas \\
20 & Rahul Adly & 65,00 & 90,00 & Tuntas \\
Nilai terendah & & 60,00 & \\
Nilai tertinggi & & 90,00 & \\
Rata-rata nilai & & 76,00 & \\
Siswa belajar tuntas & & $80,00 \%$ & \\
Siswa belajar yang & belum & & $20,00 \%$ & \\
tuntas & & & \\
\hline
\end{tabular}


Hasil penelitian yang disajikan pada Tabel 2 menunjukkan bahwa nilai terendah yang diperoleh siswa adalah 60,00 dan nilai tertinggi adalah 90,00 dengan nilai rata-rata sebesar 76,00. Jumlah siswa yang telah belajar dengan tuntas adalah $80,00 \%$. Dengan demikian, pemberian tindakan sudah memperlihatkan kemajuan yang pesat dalam meningkatkan hasil belajar siswa. Hasil belajar siswa meningkat apabila dibandingkan dengan hasil belajar yang diperoleh pada kondisi awal. Kondisi awal, rata-rata hasil belajar yang diperoleh siswa adalah 61,50. Pada siklus I, hasil ini meningkat menjadi 76,00. Ketuntasan belajar siswa juga mengalami peningkatan. Awalnya, jumlah siswa yang tuntas adalah $25,00 \%$, jumlah ini meningkat menjadi $80,00 \%$ pada Siklus I. Dengan demikian, pemberian tindakan perlu dilanjutkan pada Siklus II.

\section{Siklus II}

Berdasarkan hasil refleksi pada Siklus I, guru melanjutkan pemberian tindakan pada Siklus II. Pelaksanaan Siklus II juga dilakukan dengan empat kegiatan, yaitu perencanaan, pelaksanaan, observasi, dan refleksi. Kegiatan perencanaan terdiri atas: merumuskan tujuan pembelajaran, memilih dan mengorganisasi materi ajar, memilih sumber belajar/media pembelajaran, menyusun skenario/kegiatan pembelajaran, dan menyiapkan alat evaluasi hasil belajar.

Pelaksanaan pembelajaran untuk Siklus I difokuskan untuk mencapai standar kompetensi yaitu 8. Memahami sifat bangun ruang sederhana dan hubungan antar bangun datar dengan kompetensi dasar adalah 8.2 Menentukan jaring-jaring balok dan kubus. Setelah mengikuti kegiatan pembelajaran, siswa diharapkan dapat membuat jaring-jaring bangun ruang sederhana (balok dan kubus). Pelaksanaan kegiatan Siklus I terdiri atas tiga kegiatan yaitu kegiatan awal, kegiatan inti, dan kegiatan akhir. Kegiatan awal berupa guru mengucapkan salam; menyiapkan siswa, berdoa dan mengabsen kehadiran siswa; memberikan motivasi dan apersepsi; dan menyampaikan tujuan pembelajaran. Kegiatan inti, terdiri atas Siswa mengamati bangun ruang yang telah dibuatnya; Siswa membuka bangun ruang untuk membuat jaring-jaring Bangun ruang melalui bangun ruang yang telah disiapkan guru; Siswa memperhatikan jarring-jaring bangun ruang tersebut; Siswa disuruh menyatukan jarring-jaring yang telah disiapkan guru; Siswa membuat jarring-jaring bangun ruang lainnya. Kegiatan penutup terdiri atas siswa dengan dibimbing oleh guru membuat kesimpulan mengenai materi pelajaran. Selain itu, guru memberikan tugas dan siswa mengerjakan tugas tersebut.

Selama kegiatan pembelajaran, guru melakukan observasi terhadap siswa. Hasil observasi paa siklus II menunjukkan bahwa:

1. Siswa senang dengan mata pelajaran yang diajarkan.

2. Siswa tertarik dengan materi pelajaran.

3. Siswa berpartisipasi aktif selama kegiatan pembelajaran berlangsung

4. Siswa tertarik dan senang dengan media yang digunakan.

5. Siswa dapat menerima pelajaran dengan baik.

6. Siswa aktif menjawab pertanyaan guru dan mau berebut mengerjakan tugas dan mengerjakan soal latihan dipapan tulis.

7. Semangat siswa dalam mengikuti kegiatan pelajaran semakin meningkat.

8. Siswa aktif mengerjakan tugas dari guru.

9. Siswa sudah dapat mengerjakan tugas dari guru dengan baik.

10. Siswa dapat mengerjakan soal tes dengan baik.

Selain pengamatan, di akhir siklus guru juga melakukan tes/uji untuk menguji hasil belajar siswa. Selain peningkatan pada aktivitas belajar selama kegiatan pembelajaran berlangsung, hasil belajar siswa juga mengalami peningkatan. Hasil belajar siswa siklus II disajikan pada Tabel 3. 
Tabel 3 Hasil belajar siswa Siklus II

\begin{tabular}{clccc}
\hline No & \multicolumn{1}{c}{ Nama } & Standar & Nilai & Keterangan \\
\hline 1 & Aldi Ardianysah & 65,00 & 75,00 & Tuntas \\
2 & Aurelina Asifa & 65,00 & 80,00 & Tuntas \\
3 & Azizia Putri & 65,00 & 80,00 & Tuntas \\
4 & Cantika Citrani & 65,00 & 80,00 & Tuntas \\
5 & Farel Firdiansyah & 65,00 & 80,00 & Tuntas \\
6 & Farid M. Afif & 65,00 & 80,00 & Tuntas \\
7 & Fikri Hidayat & 65,00 & 75,00 & Tuntas \\
8 & Fadila Rama Dandi & 65,00 & 80,00 & Tuntas \\
9 & Hanifah Aulia & 65,00 & 80,00 & Tuntas \\
10 & Luthfia Firas & 65,00 & 80,00 & Tuntas \\
11 & M. Daffa Alifathul & 65,00 & 90,00 & Tuntas \\
12 & Miftahul Azwa & 65,00 & 75,00 & Tuntas \\
13 & Neysa Aina & 65,00 & 80,00 & Tuntas \\
14 & Nayla Putri Salsabila & 65,00 & 80,00 & Tuntas \\
15 & Nazwa Adriani & 65,00 & 80,00 & Tuntas \\
16 & Rivana Astssahara & 65,00 & 80,00 & Tuntas \\
17 & Reva Lina & 65,00 & 80,00 & Tuntas \\
18 & Rani Safitri & 65,00 & 80,00 & Tuntas \\
19 & Ridho Hamdani & 65,00 & 80,00 & Tuntas \\
20 & Rahul Adly & 65,00 & 90,00 & Tuntas \\
Nilai terendah & & 75,00 & \\
Nilai tertinggi & & 90,00 & \\
Rata-rata nilai & & 80,25 & \\
Siswa belajar tuntas & & $100,00 \%$ & \\
Siswa belajar yang & belum & & $0,00 \%$ & \\
tuntas & & &
\end{tabular}

Hasil penelitian yang disajikan pada Tabel 3 menunjukkan bahwa nilai terendah yang diperoleh siswa adalah 75,00 dan nilai tertinggi adalah 90,00 dengan nilai rata-rata sebesar 80,25 . Jumlah siswa yang telah belajar dengan tuntas adalah $100,00 \%$. Hasil belajar siswa meningkat apabila dibandingkan dengan hasil belajar yang diperoleh pada kondisi awal dan Siklus I. Kondisi awal, rata-rata hasil belajar yang diperoleh siswa adalah 61,50 dan pada siklus I, hasil ini meningkat menjadi 76,00. Pada Siklus II, hasil belajar kembali meningkat menjadi 80,25. Ketuntasan belajar siswa juga mengalami peningkatan. Awalnya, jumlah siswa yang tuntas adalah 25,00\%, jumlah ini meningkat menjadi $80,00 \%$ pada Siklus I, dan kembali meningkat menjadi $100,00 \%$ pada Siklus II. Dengan demikian, pemberian tindakan perlu dihentikan. Meskipun penelitian dihentikan, namun guru harus tetap selalu berupaya untuk meningkatkan kualitas pembelajaran.

Untuk memudahkan dalam membaca hasil maka dibuat rekapitulasi hasil belajar siswa dari sebelum diberikan tindakan sampai dengan setelah diberikan tindakan (Siklus I dan Siklus II). Rekapitulasi tersebut disajikan pada Tabel 4. 
Tabel 4 Rekapitulasi hasil belajar siswa

\begin{tabular}{lccc}
\hline \multicolumn{1}{c}{ Aspek } & Kondisi Awal & Siklus I & Siklus II \\
\hline Nilai terendah & 50,00 & 60,00 & 75,00 \\
Nilai tertinggi & 75,00 & 90,00 & 90,00 \\
Rata-rata nilai & 61,50 & 76,00 & 80,25 \\
Sisa belajar tuntas & $75,00 \%$ & $80,00 \%$ & $100,00 \%$ \\
Siswa belajar yang belun tuntas & $25,00 \%$ & $20,00 \%$ & $0,00 \%$ \\
\hline
\end{tabular}

\section{SIMPULAN}

Penggunaan media bangun ruang dalam mata pelajaran matematika di SDN. No. 025/XI Desa Gedang tahun 2017/2018 dapat meningkatkan aktivitas dan hasil belajar siswa. Aktivitas siswa semakin membaik. Peningkatan aktivitas ini terlihat dari meningkatnya semangat siswa dalam mengikuti rangkaian kegiatan pembelajaran. Siswa semakin aktif selama kegiatan pelajaran, siswa mampu mengajukan pertanyaan, serta siswa mampu menjawab soal tes dengan baik. Peningkatan aktivitas belajar siswa juga beriringan dengan peningkatan hasil belajar siswa. Nilai rata-rata hasil belajar siswa meningkat dari 61,50 sebelum diberikan tindakan menjadi 76,0 pada siklus I dan kembali meningkat menjadi 80,25 pada siklus II. Demikian juga halnya dengan ketuntasan belajar. Ketuntasan belajar meningkat dari $25,00 \%$ sebelum diberikan tindakan menjadi 80,00 pada siklus I dan kembali meningkat menjadi 100,00 pada siklus II.

Berdasarkan hasil, penelitian ini menyarankan sekolah untuk melakukan pelatihan rutin pada guru terutama mengenai

pendekatan/metode/model/strategi

pembelajaran yang inovatif sebagai upaya untuk meningkatkan kualitas pembelajaran. Selain itu, penelitian ini juga menyarankan guru untuk terus berusaha dalam meningkatkan pengetahuan dan keterampilan dalam melaksanakan pembelajaran. Penggunaan media pembelajaran berupa media bangun ruang dapat menjadi alternative untuk meningkatkan hasil belajar siswa pada mata pelajaran matematika, khususnya pada materi bangun ruang.

\section{DAFTAR PUSTAKA}

Abdurrahman, M. 2003. Pendidikan Bagi Anak Berkesulitan Belajar. Jakarta: Rineka Cipta

Dimyati dan Mudjiono. 2006. Belajar Dan Pembelajaran. Bandung: Alfabeta.

Halim, A. 2002. Mendifisikan media. Universitas Terbuka.

Purwanto, N. 1997. Psikologi Pendidikan. Bandung: PT. Remaja Rosdakarya

Ruseffendi. 1996. Pendidikan Matematika 3. Jakarta: Depdikbud

Rahmanelli. 2005. Skolar Jurnal Kependidikan. Vol 6. Nomor 2. Padang. UNP

Sadiman, A. S. 2007. Media Pendidikan. Jakarta. PT. Raja Grafindo Persada. 